Vol 3, No 1 (2020): Stadium - Hungarian Journal of Sport Sciences

https://doi.org/10.36439/SHJS/2020/1/5428

\title{
TÖRZS ÉS ALSÓ VÉGTAG STABILITÁSÁNAK VIZSGÁLATA LABDAJÁTÉKOSOK KÖRÉBEN
}

\author{
INVESTIGATION OF STABILITY OF THE TRUNK AND LOWER LIMBS AMONG BALL PLAYERS
}

\section{Lepp Kitti, Némethné Gyurcsik Zsuzsanna}

Debreceni Egyetem, Általános Orvostudományi Kar, Sportorvosi Tanszék, Debrecen

\section{Összefoglaló}

A különböző labdajátékok technikai hátterét az alsó végtag szempontjából a törzs és végtag izmainak összehangolt működése biztosítja. A felületes és mély hasizmok aktivitása a mozgó (rúgó, ugró végtag), valamint a támaszkodó végtag gyorsító, fékező és stabilizáló funkcióját biztosítja. A sérülés prevenció egyik alapeleme a stabilizátorok működése. Az állapotfelmérés során alkalmazott standard tesztek lehetővé teszik a játékosok fizikális kondíciójának után követését és a célzott intervenciós program tervezését.

A kutatási program célja, a labdajátékosok - kosárlabdázó, vízilabdázó, labdarugó - törzs és alsó végtag izmainak stabilizáló funkciójának mérése, a három csoport összehasonlítása a különböző technikai háttér ismeretében, valamint a célcsoportok statisztikai összehasonlítása, elemzése.

A célcsoportjaink az U16-os vízilabdás, kosaras és labdarugó versenyjátékosok, 15 fő csoportonként. Mozgásszervi összehasonlító vizsgálatot végzünk célzottan a törzs és alsóvégtagi stabilitásra kiterjedő vizsgálatokkal, speciális tesztek segítségével. Nemzetközileg is alkalmazott standard tesztek: Single leg squat teszt (sec.), Single leg squat on TOGU teszt (sec.), Single leg wallsit teszt (sec.) Single leg wall-sit with ball (sec.) Single leg bridge (sec.) Feltételezzük, hogy a standard tesztek különböző eredményeket adnak.

Az eredmények ismeretében következtethetünk, hogy mely terület, izom szinergizmus igényel fejlesztést az adott sportágban. További célok egy intervenciós program kidolgozása és megtartása, majd az utána következő ismételt állapotfelmérés, amelyből statisztikai elemzést végzünk.

Az eredményeket és a technikai hátteret figyelembe véve pedig a tornaprogram hatékonyságának megállapítása, hogy egy funkcionális szemléletmódra alapozott tornaprogram milyen mértékben befolyásolja a törzs és alsó végtag szinergista funkcióját a meghatározott tesztpozíciókban.

Kulcsszavak: állapotfelmérés, sérülés prevenció, stabilitás 


\section{Abstract}

The technical background of the various ball games is determined by its lower endpoint and ultimately provides a coordinated functional assurance of its muscles. The activity of the superficial and deep abdominal muscles is a function of the moving, kicking, jumping limbs, and the supporting, limiting and stabilizing functions of the supporting limb. A basic element of injury prevention is the operation of stabilizers. During the health check, routine testing options should be checked and a targeted intervention program developed.

The aim of the research program was to measure the core and lower final stabilization functions of ballplayers - basketball players, water polo players, and soccer players - by classifying and analyzing the various technical knowledge into three groups, as well as statistical classification and analysis of the target groups.

We tested U16 water polo, basketball and soccer players. A musculoskeletal comparative study was performed specifically with an examination of the stability of the torso and the lower limb, with special tests. Internationally Used Standard Tests: Single Leg Squat test (sec.), Single Leg Squat on TOGU test (sec.), Single leg wall-sit test (sec.) Single leg wall-sit with a ball (sec.), do a standard test with different results.

The results are known because of their full scope, the development of muscle synergism needs in a given sport. Developing and launching a unified intervention program for further goals and then compiling, with the subsequent involvement, a statistical element to end the friendship.

Developing the results and considering the technical background, determine the effectiveness of the exercise program, that is, a functional approach-based exercise program that needs to be introduced into the body and the final determination of the synergistic function from a special test position bank.

Keywords: health assessment, injury prevention, stability.

\section{ELMÉLETI HÁTTÉR}

A különböző labdajátékok technikai hátterét az alsó végtag szempontjából a törzs és végtag izmainak összehangolt működése biztosítja (PRIESKE et al., 2016; GRANACHER et al., 2014, SHARMA, 2012). A felületes és mély hasizmok aktivitása a mozgó (rúgó, ugró 
végtag), valamint a támaszkodó végtag gyorsító, fékező és stabilizáló funkcióját biztosítja (PONTAGA 2003; GISSIS, 2006). Az izmok müködéséhez szükséges optimális erő, flexibilitás, állóképesség és gyorsaság mellett fontos a mozdulatok stabilizálása, a külső erőkkel szembeni stabilizáló képesség (HORAN et al., 2014; HOSHIKAWA et al., 2013). A sérülés prevenció egyik alapeleme a stabilizátorok múködése. Az állapotfelmérés során alkalmazott standard tesztek lehetővé teszik a játékosok fizikális kondíciójának után követését és a célzott intervenciós program tervezését (LEETUN et al., 2004; BLIVEN ANDERSON, 2013).

A „Debrecen Venture Catapult Program” kutatási program keretében már vizsgáltuk a labdajátékosok scapularis régióját és az eredmények alátámasztották a feltételezett különbségeket a csapatsportok között és szeretnénk a vizsgálatot kiterjeszteni a törzs és alsó végtagi stabilizátorokra is. Így teljes képet kapunk az adott sportágak fizikális kondícióit illetően.

\section{MÓDSZER}

\section{A KUTATÁS CÉLJA}

- A labdajátékosok - kosárlabdázó, vízilabdázó, labdarugó - törzs és alsó végtag izmainak stabilizáló funkciójának mérése.

- A három csoport összehasonlítása a különböző technikai háttér ismeretében.

- A célcsoportok statisztikai összehasonlítása, elemzése, kiértékelése.

A célcsoportjaink az U16-os vízilabdás, kosaras és labdarugó versenyjátékosok, csoportonként 15-15 fő. Mozgásszervi összehasonlító vizsgálatot végzünk célzottan a törzs és alsóvégtagi stabilitásra kiterjedő vizsgálatokkal, nemzetközileg is alkalmazott speciális tesztek segítségével.

FUNKCIONÁLIS/OBJEKTÍV TESZTEK (WATANABE et al.,2016) SINGLE LEG SQUAT TESZT (SLS/sec.)

A vizsgált személy csípőszéles terpeszben, párhuzamos lábakkal áll. Karjait törzse mellett, tekintetével előre néz. Törzse egyenes. Egyik alsó végtagot nyújtva előre emeli (csípő flexió) $45^{\circ}$-os szögig. Ebből a helyzetből guggolást végez egészen $40^{\circ}$-os térd flexiós helyzetig, és tartja ezt a pozíciót (UGALDE et al., 2014) (2. ábra). A teszt 
Vol 3, No 1 (2020): Stadium - Hungarian Journal of Sport Sciences

https://doi.org/10.36439/SHJS/2020/1/5428

eredményét másodpercben rögzítjük. Értékelése megadott kategória értékek alapján történik (MISUK, 2013) (1. ábra).

\begin{tabular}{ll} 
Kategória & \multicolumn{1}{c}{$\begin{array}{c}\text { férfi } \\
\text { (second) }\end{array}$} \\
kiváló & $>100$ \\
jó & $75-100$ \\
átlagos & $50-75$ \\
átlag alatti & $25-50$ \\
rossz & $<25$
\end{tabular}

1. ábra A Single Leg Squat teszt kategória értékei secundumban kifejezve Forrás: MISUK, 2013
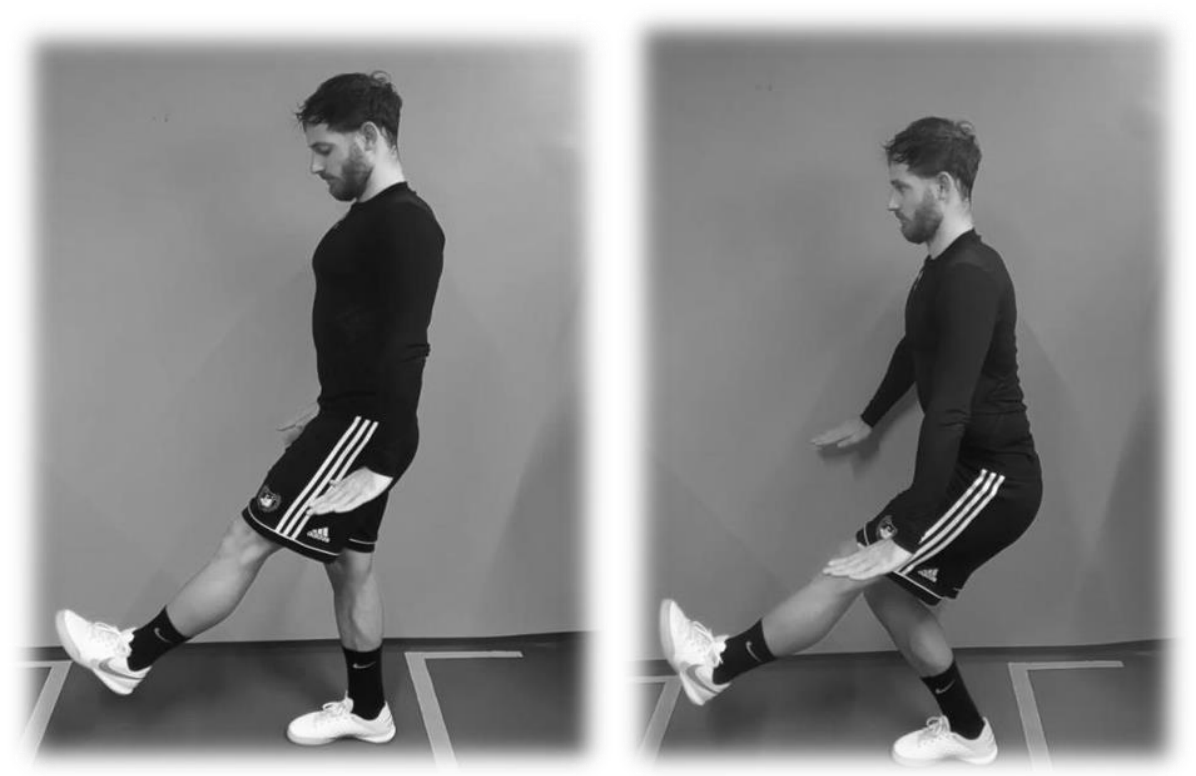

1. ábra Single Leg Squat teszt (SLS/sec.)

Forrás: saját forrás 
A vizsgált személy csípőszéles terpeszben, párhuzamos lábakkal áll a TOGU-n. Karjait törzse mellett lógatja, tekintetével előre néz. Törzse egyenes. Egyik alsó végtagot nyújtva előre emeli (csípő flexió) $45^{\circ}$-os szögig. Ebből a helyzetből guggolást végez egészen $40^{\circ}$ os térd flexiós helyzetig, és tartja ezt a pozíciót (3. ábra). A teszt eredményét másodpercben rögzítjük. Értékelése az intervenció elótt és után mért adatok összehasonlítása alapján történik.
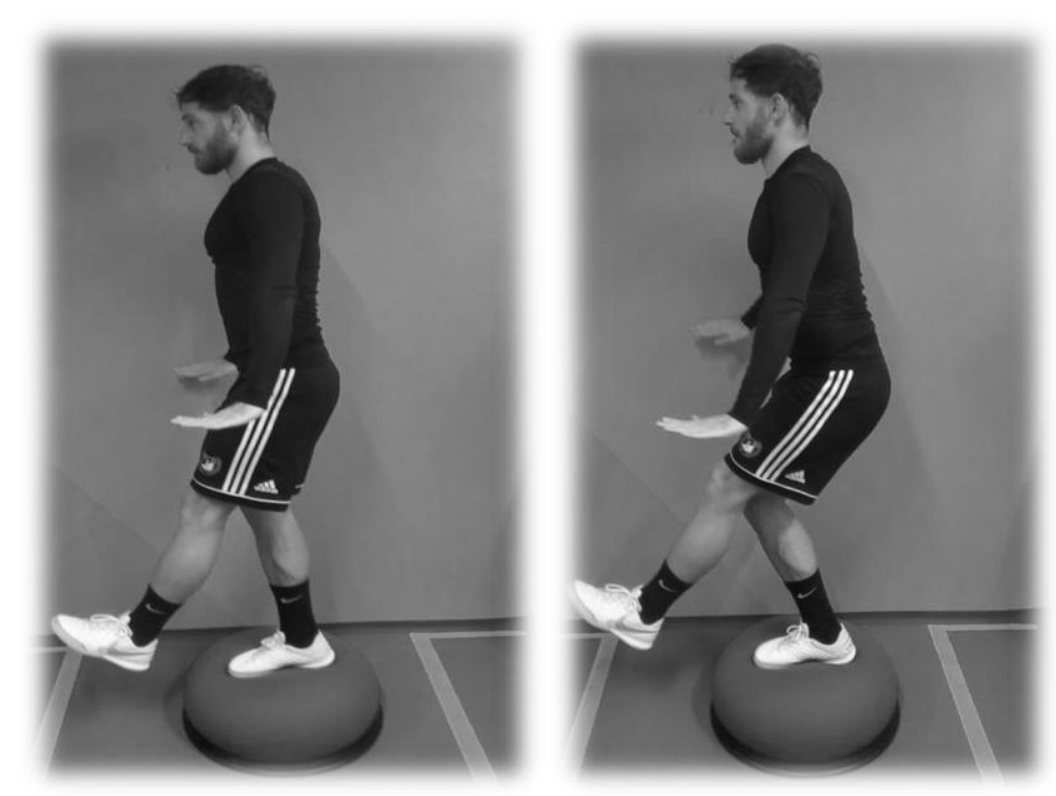

3. ábra Single Leg Squat on TOGU teszt (sec.)

Forrás: saját forrás

\section{SINGLE LEG WALL-SIT TESZT (SLWS/sec.)}

A vizsgált személy hátával a falhoz támaszkodik, csípőben, térdben $90^{\circ}$-os flexióban tartózkodik. Tekintetével előre néz, karjai lazán a törzs mellett lógnak. Ebből a kiinduló helyzetből kinyújtja az egyik alsó végtagját a comb folytatásába és tartja (4. ábra). A teszt végrehajtását másodpercben rögzítjük. Értékelése megadott kategória értékek alapján történik. Értékelése az 1. ábra alapján megadott kategória értékek alapján történik. 

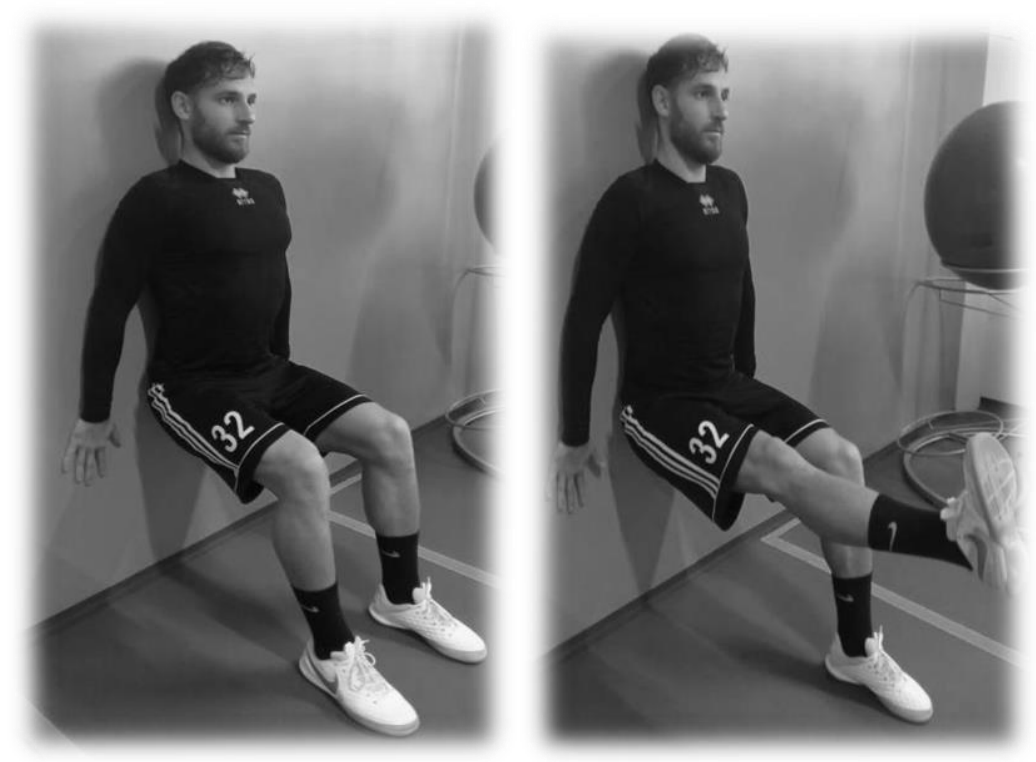

4. ábra Single Leg Wall Sit teszt (SLWS/sec.)

Forrás: saját forrás

\section{SINGLE LEG WALL-SIT WITH A BALL (sec.)}

A vizsgált személy háttal áll a falnak, a fal és a háti szakasz között egy fitt ball-t helyeztünk el. Csípőben, térdben $90^{\circ}$-os flexio. Tekintetével előre néz, karjai lazán a törzs mellett lógnak. Ebből a kiinduló helyzetből kinyújtja az egyik alsó végtagját a comb folytatásába és tartja (UGALDE et al., 2014) (5. ábra). A teszt végrehajtását másodpercben rögzítjük. Értékelése az intervenció előtt és után mért adatok összehasonlítása alapján történik
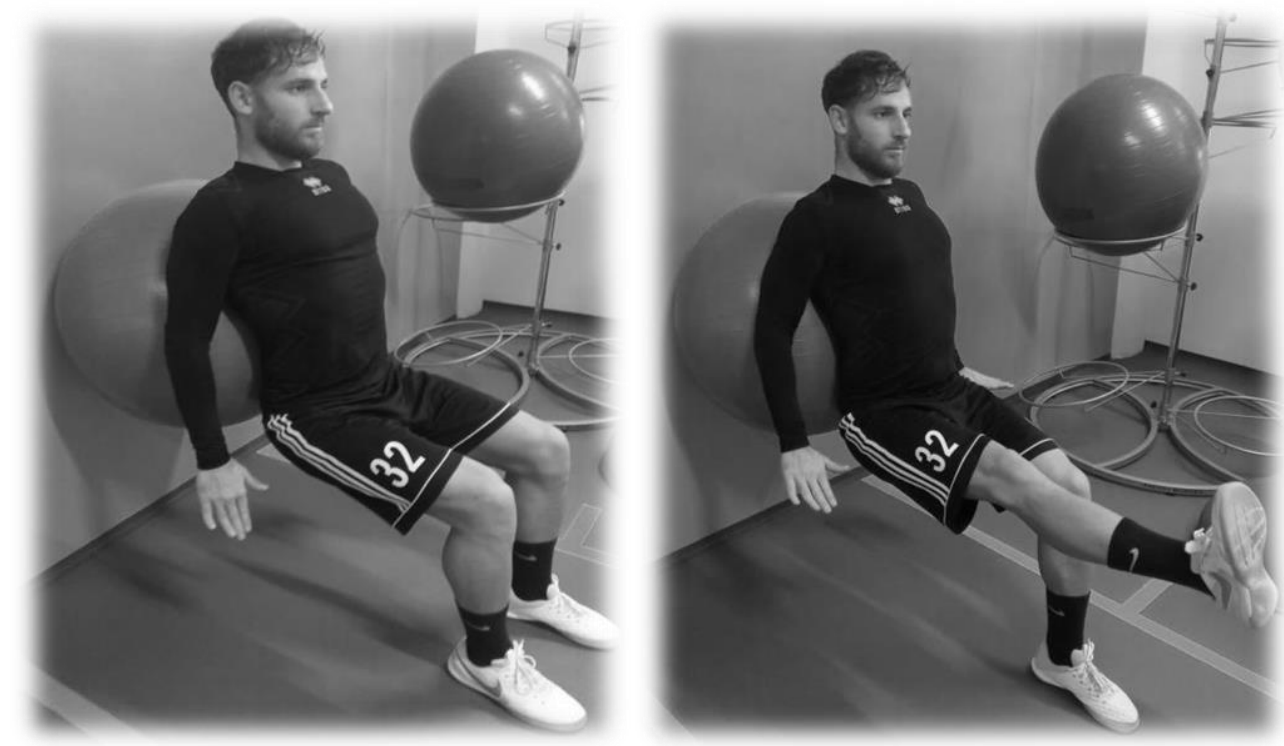

5. ábra Single Leg Wall-Sit with a ball (sec.)

Forrás: saját forrás 
Vol 3, No 1 (2020): Stadium - Hungarian Journal of Sport Sciences

https://doi.org/10.36439/SHJS/2020/1/5428

SINGLE LEG BRIDGE (sec.)

A vizsgált személy háton fekvő helyzetben talpra tett lábakkal megemeli a medencét és nyújtja a térdet a comb folytatásában. Mérjük a helyzet megtartási idejét, ameddig kompenzáló mozgásokat nem végez (6. ábra). Értékelése az intervenció előtt és után mért adatok összehasonlítása alapján történik.
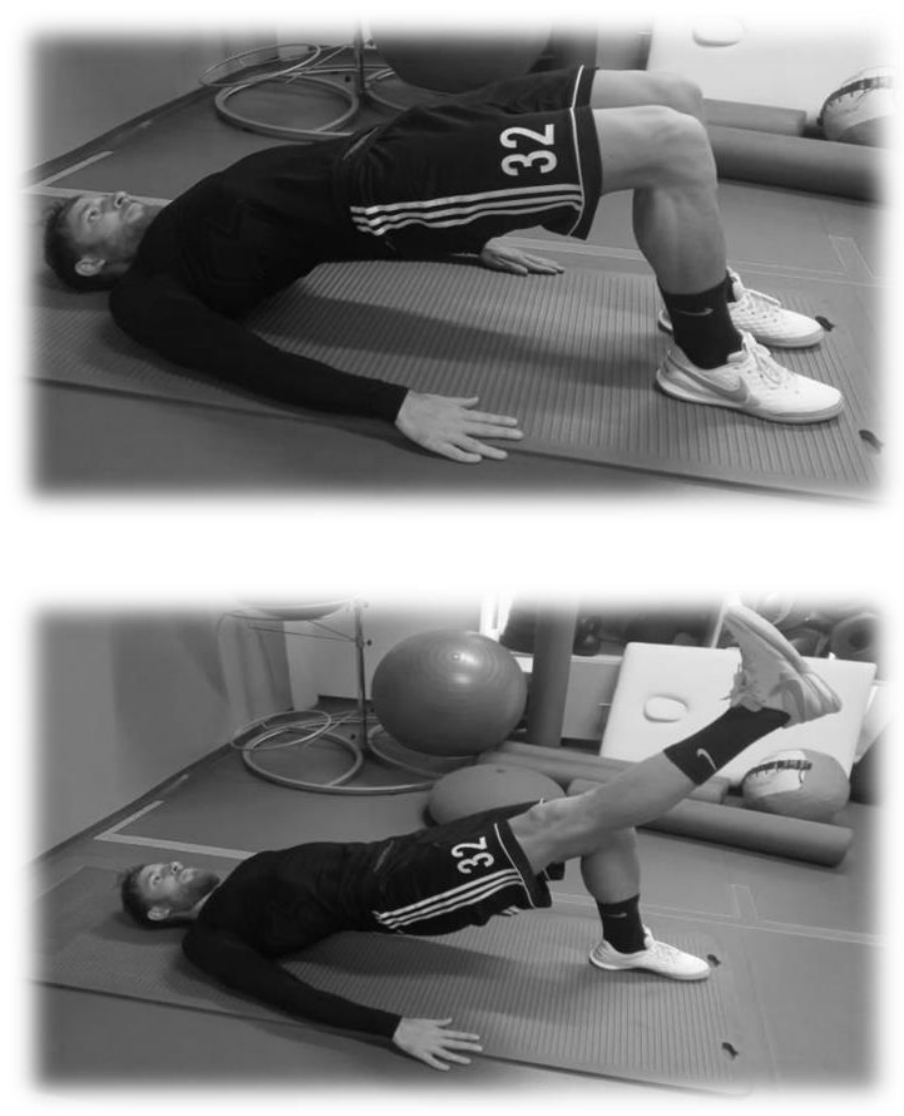

6. ábra Single Leg Bridge teszt (sec.)

Forrás: saját forrás 


\section{EREDMÉNYEK}

A három csapatsport különböző technikai hátteret igényel az alsó végtag és a törzs szempontjából. A kosarazók esetében a teljes testsúlyos emelkedés, ugrás, a labdarúgáshoz szükséges gyors és hirtelen mozdulatváltások, valamint a vízből történő kiugrás megköveteli a testrészek összehangolt működését az izomláncokon keresztül. Feltételezzük, hogy a standard tesztek különböző eredményeket adnak. Az eredmények ismeretében látható, hogy mely terület, izom szinergizmus igényel fejlesztést az adott sportágban.

A kosárlabda és vízilabda csapat felmérése 2019. október-novemberében zajlott. A kosaras csapat mérésére januárban került sor. A három csapatot statisztikailag MannWhitney teszttel F-próbával és Anovával vizsgáltuk. Csoporton belüli (jobb és baloldal összehasonlítása) és csoportok közötti összehasonlító számításokat végeztünk. A szignifikancia szintet $\mathrm{p}<0,05$-nél állapítottuk meg.

1. táblázat: A labdarúgók jobb és bal oldali teljesítményének elemzése

\begin{tabular}{lc}
\hline Funkcionális tesztek & p érték \\
\hline Single leg squat teszt & 0,33 \\
Single leg squat on Togu teszt & 0,46 \\
Single leg wall-sit teszt & 0,078 \\
Single leg wall-sit with a ball teszt & 0,5 \\
Single leg bridge teszt & 0,2 \\
\hline
\end{tabular}

Az eredmények alapján elmondható, hogy a labdarúgó csapatnál jobb és baloldal között nincs szignifikáns különbség ( $\mathrm{p}<0,05,0,01)$ (1. táblázat). 
Vol 3, No 1 (2020): Stadium - Hungarian Journal of Sport Sciences https://doi.org/10.36439/SHJS/2020/1/5428

2. táblázat: A labdarúgók eredményei (SD士átlag)

\begin{tabular}{lcc}
\hline Funkcionális tesztek & Jobb oldal & Bal oldal \\
\hline Single leg squat teszt & $\mathbf{5 0 , 5} \pm 29,2$ & $\mathbf{6 1 , 2} \pm 30,1$ \\
Single leg squat on Togu teszt & $6,5 \pm 5,5$ & $5,7 \pm 5,5$ \\
Single leg wall-sit teszt & $\mathbf{2 7 , 6} \pm 12,7$ & $\mathbf{3 6 , 1} \pm 12,9$ \\
Single leg wall-sit with a ball teszt & $28,5 \pm 12,8$ & $25,1 \pm 15,1$ \\
Single leg bridge teszt & $55,7 \pm 25,6$ & $67 \pm 23,4$ \\
\hline
\end{tabular}

A SLS teszt átlagát tekintve, jobb oldalon 50,5 másodperc, baloldalon 61,2 másodperc, ami a megadott értékekhez viszonyítva elmondható, hogy éppen eléri az átlagos $\mathrm{s}$ kategóriaértékét. A SLWS tesztnél az átlagérték jobb oldalon 27,5 másodperc, baloldalon 36,1 másodperc, amely a kategória táblázatban az átlag alattihoz sorolható (2. táblázat).

3. táblázat: $A$ vízilabdások jobb és bal oldali teljesítményének elemzése

\begin{tabular}{lc}
\hline Funkcionális tesztek & p érték \\
\hline Single leg squat teszt & 0,31 \\
Single leg squat on Togu teszt & 0,86 \\
Single leg wall-sit teszt & 0,32 \\
Single leg wall-sit with a ball teszt & 0,43 \\
Single leg bridge teszt & 0,58 \\
\hline
\end{tabular}

Az eredmények alapján elmondható, hogy nem találtunk szignifikáns különbséget a jobb és baloldal között a vízilabdás csapatnál $(\mathrm{p}<0,05,0,01)$ (3. táblázat). 
Vol 3, No 1 (2020): Stadium - Hungarian Journal of Sport Sciences https://doi.org/10.36439/SHJS/2020/1/5428

4. táblázat: $A$ vízilabdások eredményei (átlag $\pm S D$ )

\begin{tabular}{lcc}
\hline Funkcionális tesztek & Jobb oldal & Bal oldal \\
\hline Single leg squat teszt & $\mathbf{7 2 , 9} \pm 26,37$ & $\mathbf{8 6 , 9} \pm 36,34$ \\
Single leg squat on Togu teszt & $16,6 \pm 16,95$ & $12,9 \pm 13,17$ \\
Single leg wall-sit teszt & $\mathbf{3 8 , 7} \pm 20,74$ & $\mathbf{5 0 , 9} \pm 41,83$ \\
Single leg wall-sit with a ball teszt & $56,5 \pm 48,38$ & $53,1 \pm 36,78$ \\
Single leg bridge teszt & $67,7 \pm 27,04$ & $73,3 \pm 29,24$ \\
\hline
\end{tabular}

A SLS teszt átlagértéke jobb oldalon 72,9 másodperc, baloldalon 86,9 másodperc, ami az átlagos és a jó kategóriában tartozik. A SLWS tesztnél az átlag 38,7 másodperc a jobb oldalon, amely átlag alatti, a baloldalon pedig 50,9 másodperc, ami már az átlagos kategóriába sorolható (4. táblázat).

5. táblázat: A kosárlabdázók jobb és bal oldali teljesítményének elemzése

\begin{tabular}{lc}
\hline Funkcionális tesztek & p érték \\
\hline Single leg squat teszt & 0,71 \\
Single leg squat on Togu teszt & 0,45 \\
Single leg wall-sit teszt & 0,29 \\
Single leg wall-sit with a ball teszt & 0,04 \\
Single leg bridge teszt & 0,55 \\
\hline
\end{tabular}

A kapott eredmények alapján nem találtunk szignifikáns különbséget a kosaras csapat jobb és bal oldala között (p<0,05, 0,01) (5. táblázat). 
Vol 3, No 1 (2020): Stadium - Hungarian Journal of Sport Sciences https://doi.org/10.36439/SHJS/2020/1/5428

6. táblázat: A kosárlabdázók eredményei (átlag士SD)

\begin{tabular}{lcc}
\hline Funkcionális tesztek & Jobb oldal & Bal oldal \\
\hline Single leg squat teszt & $\mathbf{4 7} \pm 33,74$ & $\mathbf{5 1 , 4 7} \pm 33,74$ \\
Single leg squat on Togu teszt & $12,73 \pm 9,54$ & $15,04 \pm 9,6$ \\
Single leg wall-sit teszt & $\mathbf{2 9 , 8 7} \pm 12,51$ & $\mathbf{2 5} \pm 12,32$ \\
Single leg wall-sit with a ball teszt & $37,73 \pm 19,27$ & $24,4 \pm 14,31$ \\
Single leg bridge teszt & $65,87 \pm 29,05$ & $71,47 \pm 21,23$ \\
\hline
\end{tabular}

A SLS teszt átlagát tekintve jobb oldalon 47 másodperc, baloldalon 51,47 másodperc, ami a kategória értékekhez viszonyítva az átlagos kategóriába sorolható. Az SLWS teszt értékeinél jobb oldalon 29,87 másodperc, baloldalon 25 másodperc lett az átlageredmény, amely az átlag alatti kategóriába sorolható (6. táblázat).

7. táblázat: A csapatok jobb és bal oldali teljesítményének elemzése

\begin{tabular}{cccc} 
p érték & Jobb oldal & Bal oldal & Csapatok \\
\hline $\begin{array}{c}\text { Single leg squat } \\
\text { teszt }\end{array}$ & 0,014 & 0,015 & $\begin{array}{c}\text { vízilabda- } \\
\text { kosárlabda }\end{array}$ \\
\hline $\begin{array}{c}\text { Single leg wall-sit } \\
\text { with a ball teszt }\end{array}$ & - & 0,018 & labdarúgó-vízilabda \\
\hline
\end{tabular}

A csapatok összehasonlító elemzéséből a SLS tesztnél a vízilabda és kosaras csapat között és a SLWS tesztnél a labdarúgó és vízilabda csapat között találtunk szignifikáns különbséget $(\mathrm{p}<0,05)$ (7.táblázat). 
Vol 3, No 1 (2020): Stadium - Hungarian Journal of Sport Sciences https://doi.org/10.36439/SHJS/2020/1/5428

\section{MEGBESZÉLÉS}

További céljaink egy intervenciós program kidolgozása és megtartása a csoportok részére, majd az utána következő ismételt állapotfelmérés, amelynek eredményeiből statisztikai elemzést végzünk, technikai hátteret is figyelembe véve pedig megállapítjuk a tornaprogram hatékonyságát, hogy milyen gyakran érdemes beépíteni, egy funkcionális szemléletmódra alapozott tornaprogramot a sportolók számára.

A publikáció elkészítését az EFOP-3.6.1-16-2016-00022 „Debrecen Venture Catapult Program" projekt támogatta. A projekt az Európai Unió támogatásával, az Európai Szociális Alap társfinanszírozásával valósult meg. 
Vol 3, No 1 (2020): Stadium - Hungarian Journal of Sport Sciences

https://doi.org/10.36439/SHJS/2020/1/5428

\section{Irodalomjegyzék}

Bliven K. C. H., Anderson B. E. (2013). Core Stability Training for Injury Prevention. Sports Health, 5, (6), 514-522.

Gissis I., Papadopoulos C., Kalapotharakos V., Sotiropoulos A., Komsis G., \& Manolopoulos E. (2006). Strength and speed characteristics of elite, subelite, and recreational young soccer players. Res Sports Med, 14, (3), 205-214.

Granacher U., Schellbach J., Klein K., Prieske O., Baeyens J., \& Muehlbauer T. (2014). The role of instability with core strength training in youth. BMC Sport Sci Med Rehab, 6, 40.

Hoshikawa Y., Iida T., Muramatsu M., Ii N., Nakajima Y., Chumank K., \& Kanehisa H. (2013). Effects of stabilization training on trunk muscularity and physical performances in youth soccer players. J Strength Cond Res, 27, (11), 3142-3149.

Horan, S. A., Watson, S. L., Carty, C. P., Sartori, M., \& Weeks, B. K. (2014). Lower-limb kinematics of single-leg squat performance in young adults. Physiotherapy Canada. Physiotherapie Canada, 66, 3, 228-233.

Leetun D. R., Ireland M. L., Willson J. D., Ballantyne B. T., \& Davis I. M. (2004). Core stability measures as risk factors for lower extremity injury in athletes. Med Sci Sports Exerc. 36, 6, 926-934.

Misuk C. (2013). The Effects of Modified Wall Squat Exercises on Average Adults' Deep Abdominal Muscle Thickness and Lumbar Stability. J Phys Ther Sci. 25, (6), 689-692.

Pontaga I. (2003). Muscle strength imbalance in the hip joint caused by fast movements. Mechanics of Composite Materials. 39, 4.

Prieske 0., Muehlbauer T., Borde R., Gube M., Bruhn S., Behm D. G., \& Granacher U. (2016). Neuromuscular and athletic performance following core strength training in elite youth soccer: Role of instability. Scandinavian Journal of Medicine and Science in Sports, 26, (1), 48-5

Sharma A., Geovinson S.G., \& Singh Sandhu J. (2012). Effects of a nine-week core strengthening exercise program on vertical jump performances and static balance in volleyball players with trunk instability. J Sports Med Phys Fitness, 52, (6), 606-615. 
Vol 3, No 1 (2020): Stadium - Hungarian Journal of Sport Sciences https://doi.org/10.36439/SHJS/2020/1/5428

Ugalde V., Brockman C., Bailowitz Z., \& Pollard C.D. (2015). Single leg squat test and its relationship to dynamic knee valgus and injury risk screening. $P M R, 7$, (3), 229-35.

Watanabe M., Matsumoto, T., Ono S., Koseki H., \& Watarai K. (2016). Relationship of lower extremity alignment during the wall squat and single-leg jump: assessment of single-leg landing using three-dimensional motion analysis. Journal of Physical Therapy Science, 28, (6), 1676-1680. 